NASA/TM-2001-210245

\title{
Organic Materials Ionizing Radiation Susceptibility for the Outer Planet/Solar Probe Radioisotope Power Source
}

Eric L. Golliher, Stephen V. Pepper and James K. Sutter Glenn Research Center, Cleveland, Ohio

Prepared for the

35th Intersociety Energy Conversion Engineering Conference sponsored by the American Institute of Aeronautics and Astronautics Las Vegas, Nevada, July 24-28, 2000

National Aeronautics and Space Administration

Glenn Research Center 
This report is a preprint of a paper intended for presentation at a conference. Because of changes that may be made before formal publication, this preprint is made available with the understanding that it will not be cited or reproduced without the permission of the author.

Available from

NASA Center for Aerospace Information 7121 Standard Drive

Hanover, MD 21076

Price Code: A03
National Technical Information Service 5285 Port Royal Road Springfield, VA 22100

Price Code: A03 


\title{
ORGANIC MATERIALS IONIZING RADIATION SUSCEPTIBILITY FOR THE OUTER PLANET/SOLAR PROBE RADIOISOTOPE POWER SOURCE
}

\author{
E.L. Golliher, S.V. Pepper and J.K. Sutter \\ National Aeronautics and Space Administration \\ Glenn Research Center \\ Cleveland, Ohio 44135
}

\begin{abstract}
The Department of Energy is considering the current Stirling Technology Corporation's 55 We Stirling Technology Demonstration Convertor as a baseline option for an advanced radioisotope power source for the Outer Planets/Solar Probe project of Jet Propulsion Laboratory and other missions. However, since the Technology Demonstration Convertor contains organic materials chosen without any special consideration of flight readiness, and without any consideration of the extremely high radiation environment of Europa, a preliminary investigation was performed to address the radiation susceptibility of the current organic materials used in the Technology Demonstration Convertor.
\end{abstract}

This report documents the results of the investigation. The results of the investigation show that candidate replacement materials have been identified to be acceptable in the harsh Europa radiation environment.

\section{INTRODUCTION}

The mission to Europa imposes a very severe ionizing radiation environment to the 55-We Technology Demonstration Convertor (TDC).

The radiation from the isotope power source is insignificant when compared to radiation from the environment for 30 days in the Europa orbit. The alternator magnets and organic materials capabilities to meet these requirements were initially unknown. As it turns out, the magnets meet the requirements, and data from literature shows practically no degradation at the expected dose. However, the 55-We TDC's built to date contain some organic materials which will not survive the harsh Europa environment. A detailed assessment has shown that acceptable substitute materials exist for the organics. An effort was made to choose substitute materials close to the same family and function as the original. These were evaluated by Stirling Technology Corporation (STC) and thought to be acceptable for future TDC's. Should unexpected problems arise with the substitutes, and a second substitute must be made, there is a sufficient list of candidate radiation tolerant organic materials from which to choose.

All of the organic materials are sealed inside the pressure vessel and cannot escape to contaminate the rest of the spacecraft. The pressure of the helium inside the vessel should also act to inhibit outgassing from the organic materials. Since the coldest part of the Convertor is the pressure vessel, any outgassed organic material would deposit on this wall and should in no way affect the function of the convertor.

NASA Glenn through consultation with members of the Jet Propulsion Laboratory (JPL) staff, with Lockheed Martin in Valley Forge, PA, the STC, and commercial material vendors has carried out this evaluation. Additional coordination with the JPL Europa spacecraft materials engineers is expected as the Europa Orbiter spacecraft design progresses. Further confirmation of functional suitability of the new materials will come in the following months as two 55-We TDC's (S/N 005 and 006) will be built with these new materials to the maximum extent possible. These TDC's are scheduled for delivery and testing at NASA Glenn Research Center (GRC) in mid2000. Revised organic materials and magnets will survive the Europa radiation environment with margin. 


\section{DESCRIPTION OF ISSUES}

The two key issues are the radiation tolerance of organic materials inside the Stirling convertor and the radiation tolerance of the magnets. The approach taken was to 1) collect information from a variety of sources including a literature search, vendor inquiries, consultation with radiation, space materials, and lubrication experts; 2) estimate expected total ionizing dose inside the convertor; and 3) choose alternate materials for the flight article as warranted.

\section{ORGANIC MATERIALS - REQUIREMENTS}

The total ionizing dose from the natural space environment, Europa Orbiter Mission 01, is estimated to be $10 \mathrm{Mrad}$ (Si) with a 50 - mil aluminum housing for shielding and $4 \mathrm{Mrad}$ with a $100-$ mil shielding.

\begin{tabular}{|l|l|l|l|}
\hline $\begin{array}{l}\text { Old } \\
\text { Material }\end{array}$ & Location & Purpose & $\begin{array}{l}\text { New } \\
\text { Material } \\
\text { Mission } \\
\text { Rating }\end{array}$ \\
\hline $\begin{array}{l}\text { Xylan } \\
1620- \\
560 \text { Blue }\end{array}$ & Piston OD & $\begin{array}{l}\text { Bearing } \\
\text { Coating }\end{array}$ & $\begin{array}{l}\text { Xylan } \\
1054 / 1\end{array}$ \\
\hline $\begin{array}{l}\text { Polyi- } \\
\text { mide } \\
\text { (Kapton) }\end{array}$ & $\begin{array}{l}\text { Wire } \\
\text { Insulation }\end{array}$ & $\begin{array}{l}\text { Wire } \\
\text { Insula- } \\
\text { tion }\end{array}$ & $\begin{array}{l}\text { Accept- } \\
\text { able as is } \\
11\end{array}$ \\
\hline $\begin{array}{l}\text { Dolph } \\
1057 \\
\text { Epoxy }\end{array}$ & Coils & $\begin{array}{l}\text { Bonding } \\
\text { Agent }\end{array}$ & $\begin{array}{l}\text { EC2216 } \\
\text { 11 }\end{array}$ \\
\hline $\begin{array}{l}\text { Loctite } \\
420\end{array}$ & $\begin{array}{l}\text { Stator } \\
\text { Lamination }\end{array}$ & $\begin{array}{l}\text { Wicking } \\
\text { Adhesive }\end{array}$ & $\begin{array}{l}\text { Loctite } \\
4014 / 2\end{array}$ \\
\hline $\begin{array}{l}\text { Scotch- } \\
\text { weld }\end{array}$ & $\begin{array}{l}\text { Magnets, } \\
\text { Stator }\end{array}$ & $\begin{array}{l}\text { Epoxy } \\
\text { Adhesive }\end{array}$ & $\begin{array}{l}\text { EC2216 } \\
11\end{array}$ \\
\hline $\begin{array}{l}3 \mathrm{M} \text { heat } \\
\text { shrink } \\
\text { tubing }\end{array}$ & $\begin{array}{l}\text { Wire } \\
\text { connector }\end{array}$ & $\begin{array}{l}\text { Electrical } \\
\text { insulation }\end{array}$ & $\begin{array}{l}\text { Raychem } \\
\text { PVDF } / 1\end{array}$ \\
\hline Kapton & Edge of & Electrical & Permacel \\
\hline
\end{tabular}

\begin{tabular}{|l|l|l|l|}
\hline $\begin{array}{l}\text { tape } \\
\text { (KA00) }\end{array}$ & Stator & Wire & $\begin{array}{l}\text { or 3M } \\
\text { Y966/1 }\end{array}$ \\
\hline $\begin{array}{l}\text { Garolite } \\
\text { G-10 }\end{array}$ & $\begin{array}{l}\text { Coils, } \\
\text { Laminates }\end{array}$ & $\begin{array}{l}\text { Electrical } \\
\text { Insulation }\end{array}$ & $\begin{array}{l}\text { Accept- } \\
\text { able as is } \\
11\end{array}$ \\
\hline $\begin{array}{l}\text { TFE } \\
\text { Coating }\end{array}$ & $\begin{array}{l}\text { Wires for } \\
\text { Feed } \\
\text { Through }\end{array}$ & $\begin{array}{l}\text { Electrical } \\
\text { Insulation }\end{array}$ & $\begin{array}{l}\text { Raychem } \\
\text { PVDF } / 1\end{array}$ \\
\hline $\begin{array}{l}\text { TFE } \\
\text { Bumper }\end{array}$ & $\begin{array}{l}\text { End of } \\
\text { Piston }\end{array}$ & $\begin{array}{l}\text { Power } \\
\text { Piston } \\
\text { Bumper }\end{array}$ & $\begin{array}{l}\text { PVDF or } \\
\text { EFTE } \\
\text { machined } \\
\not 1\end{array}$ \\
\hline
\end{tabular}

Mission Rating

$1=$ Current Materials acceptable

$2=$ Acceptable, requires dose calculations

$3=$ Acceptable, with dose calculations and test data

4= Questionable, conclusive proof required

$5=$ Unacceptable

\section{DESCRIPTION OF ORGANICS}

Xylan $1620-560$ blue is a Teflon-based lubricant coating. Teflon cannot survive in the Europa radiation environment. It can be replaced by Xylan 1054, which is a MoS ${ }_{2}$-based coating. STC has experience with Xylan coatings, so staying within same family of lubricants is low-risk. The highpressure dry helium environment will negate any worries of $\mathrm{MoS}_{2}$ humidity and water vulnerability. Xylan is used as a lubricant on the outer diameter of the piston. Although there is no contact during nominal operation, the Xylan is needed to facilitate components/parts installation in the build-up process and to ensure no metal-to-metal contact during nonoperating and launch vehicle ascent conditions. There was an extensive investigation of a replacement for the original Xylan-blue, since the original contained Teflon, a material which cannot withstand the $4 \mathrm{Mrad}$ expected dose. Teflon is notably very poor in even low-level ionizing radiation environments. A type of Xylan that uses Molybdenum disulfide as the active lubricant component was selected as a replacement. Since 
the components of this type of Xylan are very radiation resistant, it follows that the Xylan itself is rad-hard. No radiation testing data is available on the chosen Xylan.

The interior of the $55 \mathrm{~W}$ Stirling Convertor that is proposed for the Europa mission will be subjected to an ionizing radiation dose of about 4 Mrads ( $\mathrm{Si}$ ) during the mission. The lubricant on the Convertor's piston must survive this dose. The present lubricant is not a satisfactory choice for this service condition and a substitute must be found. A substitute is recommended in this memo.

The present lubricant is Xylan 1620-560 (blue) manufactured by Whitford Corporation, West Chester, PA. The active lubricant in this product is PTFE (polytetrafluoroethylene, Teflon) and this PTFE is, according to Whitford held in a polyamide-imide resin binder. The piston lubricant is present to protect the piston and cylinder wall during handling, assembly and initial operation (run-in). It is also expected to be protective during the vibration of launch and other initial vehicle maneuvers. It is not expected to be operational past this point, since the Convertor is designed for a piston-cylinder wall clearance of .001" during normal operation, during which there is no contact of the piston with the cylinder wall. Although these service requirements on the piston lubricant appear to be very mild, the radiation environment is very severe on the PTFE and results in undesirable emission of gaseous fluorocarbon breakdown products and embrittlement of the PTFE. Such embrittlement may result in the formation of a wear particle that could be caught between the piston and cylinder wall and jam the Convertor, a catastrophic event. Thus a lubricant such as the one presently used should be avoided and a recommendation should be made for a substitute that is not as vulnerable to ionizing radiation.

This recommendation is motivated by the wish to retain the positive experience that STC has had with the Xylan product they have used up to the present. The $1620-560$ is really one of a family of products, all going by the generic name of Xylan, but formulated with different active lubricants in the binder. Xylan 1054 is identified here as a radiation-resistant substitute for the present lubricant. This product uses $\mathrm{MoS}_{2}$ (Molybdenum Disulfide) powder lubricant formulated in the polyamide-imide resin binder. $\mathrm{MoS}_{2}$ is an inorganic mineral that is invulnerable to ionizing radiation. It is also noted that the helium environment in the Convertor is an ideal environment for the tribological application of $\mathrm{MoS}_{2}$, which does not perform well in either moisture or oxygen. The binder, however, is still an organic material that merits some comment. According to Whitford, the $500^{\circ} \mathrm{F}$ cure that the neat polyamide-imide resin undergoes during its application on the workpiece converts it entirely to polyimide. Polyimide is extremely resistant to ionizing radiation. Polyimide retains its properties up to a dose of $100 \mathrm{Mrads}^{1}$. In addition, the polyamideimide is a good tribological material in its own right and is marketed for this purpose by BPAmoco under the name of Torlon. Quoting from the BPAmoco website:

"Torlon 8 polyamide-imide provides exceptional strength at high temperatures, excellent resistance to creep and wear plus the benefits of injection mouldability. The material has unmatched frictionwear characteristics in the most severe service environments. Typical applications for Torlon polyamide-imide include chemical processing equipment, bearings and seals, automotive/aviation components, electrical/electronic devices, rotating machinery, oil drilling equipment, and industrial equipment."*

The BPAmoco design handbook also indicates radiation resistance up to at least $10 \mathrm{Mrads}$

Polyimide (Kapton) wire insulation does not need to be replaced. The radiation tolerance of Kapton is excellent, as it shows no degradation until about 400 Mrads. This will be used on the square wire in the magnet windings, "Polyimide-ML". Kapton is used as wire insulation. It shows only incipient to mild damage below $10^{8}$ Rads according to page 9 of reference 1. Our dose is less than $4 \times 10^{6}$ Rads as listed in on page 152 of Reference 2.

Epoxy Resin Paste (with aromatic-type curing agent) is acceptable to 1E+09 rads per NASA-CR-1781, Hanks and Hamman, July 1971, as referenced by JPL.

*C1999 BP Amoco p.l.c. and its affiliates 
Loctite 420 can be replaced with Loctite 4014 . This is almost same adhesive, but has test data for radiation hardness. 4014 retains $83 \%$ of shear strength after exposure to 7 Mrads. Loctite 420 was used as a wicking adhesive to bond the stator laminations together. The laminations are a stack of Hiperco 50 plates. The plates are put in a moist oven to form an oxide layer. The oxide layer acts as an electrical insulator. The mover laminations are bolted to the moving rod. These laminations interact with the magnetic field and cause a current to flow in the stationary coils. The viscosity of the uncured Loctite 420 is around 1 to 5 centipoise ( $1 \mathrm{cp}$ is typical for water). The low viscosity is needed so that the adhesive will "wick" in between the sandwich layers, after the sandwich is assembled. The Loctite technical representative recommended 4014 as a substitute when asked about a similar adhesive to 420 suitable for a radiation environment. The technical representative knew of Loctite application in the medical field for use in devices that must undergo radiation sterilization. Loctite 4014 is also similar in viscosity to 420 and can handle high temperature $\left(80^{\circ} \mathrm{C}\right)$. The Loctite 4014 data sheet appears to imply that Loctite has test data for 4014 showing only small degradation to 7 Mrads. A careful reading of the datasheet leaves some doubt that data for 4014 is the actual material data being reported. Nevertheless, 4014 is the chosen substitute. NASA materials engineers identified through contacts with technical representatives at Loctite, that the 4014 glass transition temperature of $120^{\circ} \mathrm{C}$ is near that of 420 .

Tra-Con Tra-Bond F113 was a material initially considered as a candidate replacement for Loctite 420. After GRC obtained a copy of the technical data sheet from Tra-Con, the glass transition temperature of $45^{\circ} \mathrm{C}$ was found to be too low for our application.

Scotch-weld DP-460 adhesive is used on the stator magnets. According to $3 \mathrm{M}$, a good substitute is $3 \mathrm{M}-\mathrm{EC} 2216$. This is used in the terrestrial nuclear power industry. Also, JPL identifies 3M-EC2216 as a typical spacecraft adhesive good to $1 E+08$ RADs or better. STC has used this recently in assembling some stator magnets. The materials used at three locations were replaced with EC2216, a material commonly used in JPL spacecraft in high radiation environments and one specifically recommended in by $\mathrm{JPL}^{3}$. The application is a little higher temperature than used in JPL spacecraft, so some investigation as to the adequacy for the Stirling application on the part of a NASA Glenn materials expert was undertaken.

EC 2216 will replace Dolph CD-1057 Epoxy and Permabond 919, 920 on the stator coils. Dolph CD-1057 Epoxy is a two-part epoxy used on the stator coils. A layer of Dolph CD-1057 is applied over the coils, which are square copper wires. It covers the coils, holds the coils together, has a glassy, varnish-like appearance, and is brittle. Because there was no radiation testing data from the manufacturer, the decision to substitute this epoxy with EC2216 was made. EC2216 is on the JPL recommended list for adhesives for the Outer Planet/Solar Probe project. However, specific radiation testing data is not available. STC also used another adhesive for this same purpose, Permabond 919 and 920 . Both are being replaced by EC2216. Permabond also has no data on radiation hardness. The adhesive is actually called "Powerbond." It requires a secondary cure at a high temperature to get the cross-linking for high temperature capability. EC2216 does not require a secondary cure for its high radiation tolerant properties. In the initial efforts with the 2216, STC found it to be more pliable that the Dolph or Permabond. STC also tested a coil bonded with 2216 in a furnace at $100{ }^{\circ} \mathrm{C}$. The 2216 strength appeared to be acceptable to STC. This will be further evaluated during testing of the TDC's $5 / 6$ at STC and NASA GRC.

EC2216 will replace Scotch-weld DP-460 on the stator magnets/laminations bond and stator lamination/bobbin bond.

Scotchweld DP-460 is used to bond the stator magnet to the laminations, and to bond the bobbin to the laminations. The bobbin is a center core of plastic material around which the coils are wound. No radiation data was available. The $3 \mathrm{M}$ technical representative was contacted to suggest a substitute, and she suggested 3M-EC2216. The shear strength for DP-460 is higher than for 2216 at the operating temperature ( 700 psi versus 400 psi lap shear at $82{ }^{\circ} \mathrm{C}$ ). Both degrade with temperature. 
Dexter Hysol was considered as an alternative to EC 2216. NASA asked Schaeffer Magnetics to help with a recommendation for a wicking adhesive typically used for electric motor coils for space application. Shaeffer Magnetics is a company known for supplying electric motors used in satellites for defense, commercial, and NASA missions. The company revealed they use Dexter Hysol EA 9396 on some coils in their space-rated motors. However, the glass transition temperature was reported to be only $76{ }^{\circ} \mathrm{C}$ by the Dexter Hysol tech rep. This may not be adequate for our slightly higher temperature application, where the alternator magnets may operate near $80^{\circ} \mathrm{C}$. Dexter Hysol was not recommended for this application.

$3 \mathrm{M}$ heat shrink tubing used around the wire connectors. Wire insulation, in general, could be Crosslinked PVDF and ETFE insulation; both pass 500 Mrads.

Kapton Tape (KAOO) Kapton portion is acceptable. Several sources are available for flight-qualified Kapton tape.

Heat shrink tubing currently used will be replaced with tubing made of Kynar, which is PVDF, polyvinylidene flouride. PVDF is identified in reference 1 as incipient to mild damage to almost $10^{7}$ Rads. This agrees with JPL information, which reports PVDF hard to 500 Mrads or better.

Garolite G-10. G-10 is not a problem at $4 \mathrm{Mrad}$. This is an epoxy-glass laminate. Reference 1, page 25, reports that epoxy glass laminate is capable of withstanding $10^{8}$ Rads.

TFE Wire insulation for general wire insulation is not acceptable. JPL recommends replacement with Crosslinked PVDF or EFTE. Teflon cannot withstand even low levels of ionizing radiation. The Teflon must be replaced. PVDF is a common alternative for wire insulation. PVDF, polyvinylidene flouride, is identified in reference 1 , page 9 , as incipient to mild damage to almost $10^{7}$ Rads. This agrees with JPL information, which reports PVDF hard to 500 Mrads or better.

TFE as the piston bumper material is unacceptable. STC will replace TFE with PVDF or EFTE.

\section{SUMMARY}

In the Fall of 1999, several critical issues were identified as possible "show-stoppers" for the application of a Stirling Convertor to an advanced radioisotope power source. This investigation has shown that a list of suitable organic material replacements has been found, and that there are no "show-stoppers." Interested parties should be aware of upcoming functional testing of additional baseline 55 We Stirling convertor units. These additional units will be the first time the replacement organics are used in a Stirling convertor. No issues are expected. At the time of this report, the testing will take place in CY 2000 at NASA Glenn Research Center and at STC. The overall Stirling technology plan at Glenn is described in Reference 4.

A note about the nuclear fuel radiation is warranted. The radiation produced by the nuclear fuel was considered negligible with respect to damaging the organics inside the convertor, in comparison to the environmental radiation. This should be re-visited when the final SRPS design integration concept is available. The distance of the organics from the GPHS modules is one of the key parameters. It is expected that, in any design, the nuclear fuel radiation will always be negligible when compared to the Europa environment radiation.

Some mention of environmental radiation dose calculations is needed. Interested parties should probably take a fresh-look at the necessity of dose calculations when a final SRPS concept becomes available. There were no computer calculations performed for dose estimates in the organics for this investigation. As a guideline, the estimated ionizing dose in Silicon of 4 Mrads behind 100 mils aluminum shielding was used. Radiation deposited in the material Silicon is a typical ionizing radiation calculation, because most ionizing radiation damage assessments are interested in survivability of electronics. It is possible that the dose in the various organics may be different for the same ionizing radiation source. The difference from Silicon is thought to be negligible for the scope of this report. The flight unit Stirling Convertor pressure vessel is anticipated to be stainless steel or titanium with wall thickness near 60 mils. However, there is very high confidence that the intrinsic radiation shielding provided by the final design of the pressure vessel, as is the case with the current design, will exceed that of an equivalent design provided by 100 mils of 
aluminum. Therefore, the total dose of 4 Mrads is reasonably conservative for this level of investigation. Two further points to mention which may decrease conservatism. First, computer ray-tracing modeling considering the real geometry and the additional shielding of various structural metallic and non-organic parts inside the convertor will probably show a lower dose than 4 Mrads. Second, consideration of the radiation spectra near Europa may show less damaging effects than a Total lonizing Dose (TID) of 4 Mrads, although total dose methods were considered adequate for organics at this level of investigation.

Radiation testing was not mentioned in this report, but is always a consideration for radiation hardness verification. The decision to perform radiation testing on individual materials or to perform radiation testing on the convertor at the unit level should be made later, in concert with the spacecraft-level radiation control plan. There are considerations of radiation design margin (RDM), which may be different for organics than for electronics. Although it appears no radiation testing is needed on the Stirling convertor organics nor on the convertor at the unit level, a fresh-look study on this matter is warranted in future months. JPL, as the overall spacecraft integrator, is expected to further refine requirements for spacecraft level and unit level radiation hardness for all materials and electronics aboard the spacecraft.

\section{REFERENCES}

1. Hanks, C.L., and Hamman, D.J., Radiation Effects Design Handbook, Section 3. Electrical Insulating Materials and Capacitors, NASA CR1787, Prepared for the Radiation Effects Information Center, Battelle Memorial Institute, Columbus, Ohio, July 1971.

2. JPL, Outer Planet/Solar Probe Review, Arcadia, CA. Veteran's Day, November 12, 1999.

3. Willis, P.B., JPL, "X-2000 Mission Materials Radiation Effects," presentation to X-2000 Project, May 26, 1998.

4. Thieme, L.G., "NASA GRC Technology Development Project for a Stirling Radioisotope Power System," $35^{\text {th }}$ IECEC, Las Vegas, NV, July 24-28, 2000. 
Public reporting burden for this collection of information is estimated to average 1 hour per response, including the time for reviewing instructions, searching existing data sources gathering and maintaining the data needed, and completing and reviewing the collection of information. Send comments regarding this burden estimate or any other aspect of this collection of information. including suggestions for reducing this burden, to Washington Headquarters Services. Directorate for Intormation Operations and Reports, 1215 Jefferson Davis Highway. Suite 1204, Arlington, VA 22202-4302, and to the Office of Management and Budget, Paperwork Reduction Project (0704-0188), Washington, DC 20503.

\begin{tabular}{l|l|l} 
1. AGENCY USE ONLY (Leave blank) & 2. REPORT DATE & 3. REPORT TYPE AND DATES COVERED
\end{tabular}

\section{TITLE AND SUBTITLE}

January 2001

Technical Memorandum

Organic Materials Ionizing Radiation Susceptibility for the Outer

Planet/Solar Probe Radioisotope Power Source

6. AUTHOR(S)

5. FUNDING NUMBERS

Eric L. Golliher and Stephen V. Pepper

7. PERFORMING ORGANIZATION NAME(S) AND ADDRESS(ES)

National Aeronautics and Space Administration

John H. Glenn Research Center at Lewis Field

Cleveland, Ohio 44135-3191

8. PERFORMING ORGANIZATION REPORT NUMBER

E-12364

9. SPONSORINGMONITORING AGENCY NAME(S) AND ADDRESS(ES)

National Aeronautics and Space Administration

Washington, DC 20546-0001

10. SPONSORINGMONITORING AGENCY REPORT NUMBER

NASA TM-2001-210245

AIAA-2000-3077

\section{SUPPLEMENTARY NOTES}

Prepared for the 35th Intersociety Energy Conversion Engineering Conference sponsored by the American Institute of Aeronautics and Astronautics, Las Vegas, Nevada, July 24-28, 2000. Responsible person, Eric L. Golliher, organization code $5490,216-433-6575$.

12a. DISTRIBUTION/AVAILABILITY STATEMENT 12b. DISTRIBUTION CODE

Unclassified - Unlimited

Subject Categories: 20 and 44

Distribution: Nonstandard

This publication is available from the NASA Center for AeroSpace Information. 301-621-0390.

13. ABSTRACT (Maximum 200 words)

The Department of Energy is considering the current Stirling Technology Corporation 55 We Stirling Technology Demonstration Convertor as a baseline option for an advanced radioisotope power source for the Outer Planets/Solar Probe project of Jet Propulsion Laboratory and other missions. However, since the Technology Demonstration Convertor contains organic materials chosen without any special consideration of flight readiness, and without any consideration of the extremely high radiation environment of Europa, a preliminary investigation was performed to address the radiation susceptibility of the current organic materials used in the Technology Demonstration Convertor. This report documents the results of the investigation. The results of the investigation show that candidate replacement materials have been identified to be acceptable in the harsh Europa radiation environment.

\begin{tabular}{|c|c|c|}
\hline \multicolumn{3}{|l|}{ 14. SUBJECT TERMS } \\
\hline $\begin{array}{l}\text { 17. SECURITY CLASSIFICATION } \\
\text { OF REPORT } \\
\text { Unclassified }\end{array}$ & $\begin{array}{l}\text { 18. SECUAITY CLASSIFICATION } \\
\text { OF THIS PAGE } \\
\text { Unclassified }\end{array}$ & $\begin{array}{l}\text { 19. SECURITY CLASSIFICATION } \\
\text { OF ABSTRACT } \\
\text { Unclassified }\end{array}$ \\
\hline
\end{tabular}

NSN 7540-01-280-5500 